\title{
Pengaruh Suplementasi L-Arginine Dalam Pakan terhadap Pertambahan Bobot Badan, Konsumsi Pakan dan Konversi Pakan Ayam Broiler
}

\author{
Charles V. Lisnahan ${ }^{\mathrm{a}}$, Alfonsus Seran ${ }^{\mathrm{b}}$ dan Gerson Frans Bira ${ }^{\mathrm{c}}$ \\ ${ }^{a}$ Fakultas Pertanian, Universitas Timor, Kefamenanu, TTU - NTT, 85613 Indonesia, email: charleslisnahan03@ gmail.com \\ ${ }^{b}$ Fakultas Pertanian, Universitas Timor, Kefamenanu, TTU - NTT, 85613 Indonesia, email: seranalfonsus@ gmail.com \\ ${ }^{c}$ Fakultas Pertanian, Universitas Timor, Kefamenanu, TTU - NTT, 85613 Indonesia, email: gersonbira@ yahoo.co.id \\ Article Info

\section{Abstrak}

\section{Article history:}

Received 15 Juli 2021

Received in revised form 25 Juli 202 Accepted 31 Juli 2021

DOI:

https://doi.org/10.32938/ja.v6i3.1415

Keywords:

Ayam Broiler

L-Arginine

Pertambahan

Bobot Badan

Konsumsi Pakan

Konversi Pakan
Penelitian ini bertujuan untuk mengetahui pengaruh suplementasi L-arginine terhadap pertambahan bobot badan, konsumsi pakan dan konversi pakan ayam broiler. Penelitian dilaksanakan di kandang program studi peternakan fakultas pertanian selama 6 minggu sejak bulan maret sampai mei 2021. Penelitian ini menggunakan 96 ekor ternak ayam broiler berumur 1 hari atau day old chick (DOC) strain CP 707. Metode yang digunakan dalam penelitian ini adalah eksperimen dengan rancangan acak lengkap (RAL) pola serarah yang terdiri dari 4 perlakuan dan 4 kali ulangan, sehingga terdapat 16 unit percobaan. Setiap unit percobaan diisi 6 ekor ayam broiler. Perlakuan yang diberikan adalah: $\mathrm{T}_{0}: 100 \%$ pakan $\mathrm{BR} 2, \mathrm{~T}_{1}: 99,5 \%$ pakan $\mathrm{BR} 2+0,5 \%$ L-arginine, $\mathrm{T}_{2}: 99,25 \%$ pakan $\mathrm{BR} 2+0,75$ L-arginine, $\mathrm{T}_{3}: 99,00$ pakan BR2 $+1,00 \%$ L-arginine. Variabel yang diamati dalam penelitian ini adalah pertambahan bobot badan, konsumsi pakan dan konversi pakan ayam broiler. Data yang diperoleh dianalisis menggunakan analisis sidik ragam dan uji dancan. Hasil analisis sidik ragam menunjukkan bahwa perlakuan berpengaruh nyata terhadap pertambahan bobot badan dan konversi pakan $(\mathrm{P}<0,05)$, sedangkan konsumsi pakan berpengaruh tidak nyata $(\mathrm{P}>0,05)$. Disimpulkan bahwa suplementasi $L$-arginine $0,75 \%$ meningkatkan pertambahan bobot badan dan konversi pakan ayam broiler.

\section{Pendahuluan}

Ayam broiler merupakan jenis ternak penghasil daging yang di kembangkan untuk pemenuhan kebutuhan protein hewani bagi masyarakat, karena harganya yang lebih terjangkau dibanding ternak penghasil daging lainnya. Menurut Badan Pusat Statistik, (2019), Populasi ayam broiler pada tahun 2015, 2016, 2017, 2018 dan 2019 di provinsi Nusa Tenggara Timur adalah 2.687.269, 4.838.166, 11.927.711, 10.954.699, dan 17.768.227 ekor. Setiap tahun kebutuhan daging ayam broiler meningkat, untuk memenuhi kebutuhan daging ayam broiler untuk masyarakat perlu adanya peningkatan mutu dalam pemeliharaan ayam broiler. Ayam broiler mempunyai sifat yang cepat betumbuh dan sangat efisien dalam menggunakan pakan, massa panen yang singkat jika ditunjang dengan pakan yang berkualitas baik. Yuwanta, (2004) menyatakan ayam broiler merupakan ayam yang memiliki kecepatan bertumbuh pesat dalam kurun waktu yang singkat.

Pemiliharaan ayam broiler sangat dipengaruhi oleh faktor genetik, keadaan lingkungan seperti pakan, dan manajeman lainya. Herlina et al (2015) menyatakan bahwa pertumbuhan ayam broiler yang diberi jenis ransum BR1 dan BR2 menghasilkan bobot badan 1895,92-2029,57. Penampilan ayam broiler yang baik apabila sistem pemeliharaannya secara intensif menggunakan bibit unggul, pakan yang berkualitas tinggi, serta perkandagan dan memperhatikan aspek kesehatan dan kenyamanan ternak (Nuriyasa, 2003). Ayam broiler dapat mengkonversi ransum dalam jumlah kecil sehingga dapat meningkatkan nilai efisiensi penggunaan pakan dan pertumbuhan yang cepat, hal ini dapat terjadi jika ditunjang dengan pakan yang berkualitas baik dengan kandungan nutrisi yang lengkap. Konversi pakan dapat dihitung dengan membandingkan jumlah pakan yang dikonsumsi dan pertambahan bobot badan dalam jangka waktu tertentu. Untuk menilai efisiensi penggunaan pakan dapat di ukur dengan melihat pertambahan bobot badan ayam broiler.

Pakan merupakan salah satu faktor yang berpengaruh besar terhadap pertumbuhan perlu diperhatikan dalam pemeliharaan ayam broiler. pakan yang baik harus mencukupi dari segi kualitas, kuantitas dan kontiunitas Dalam Pemberian pakan pada ayam harus memperhatikan keseimbangan protein, energi, dan vitamin. Suprijatna et al. (2010) menyatakan bahwa pakan merupakan campuran dari berbagai macam bahan organik dan anorganik yang diberikan pada ternak untuk memenuhi kebutuhan zat-zat makanan yang dibutuhkan bagi pertumbuhan, perkembangan dan reproduksi, untuk mencapai pertumbuhan dan produksi yang maksimal, perlu diperhatikan jumlah dan kandungann zat-zat makanan ternak yang harus memadai. Kandungan nutrisi pakan BR2 yaitu kadar air 14,0\%, protein kasar 19,0\%, lemak kasar 5,0\%, serat kasar 6,0\%, abu $8,0 \%$, kalsium (Ca) $1,1 \%$, fosfor (+fitase) $0.45 \%$, urea, aflatoxin total $50 \mu \mathrm{g} / 50 \mathrm{~kg}$ dan asam amino total yang digunakan yaitu lisin $1,05 \%$, metionn $0,40 \%$, metionin+ sistin) $0,75 \%$, treonin $0,65 \%$, triptofan $0,18 \%$ (PT.Wonokoyo Jaya coporindo). Dalam tubuh ayam broiler tidak dapat memproduksi asam amino esensial oleh karena itu perlu ditambahkan dalam pakan.

Salah satu nutrien utama pada ayam broiler yang perlu diperhatikan adalah protein dan salah satu penyusun asam amino adalah asam amino $L$ arginine. Asam amino adalah nutrien yang sangat diperlukan dan diperhatikan dalam pemeliharaan ayam broiler, salah satu contohnya adalah asam amino L-arginine. L-arginine menjadi salah satu asam amino penting yang dinilai sebagai esensial pada ayam broiler, karena merupakan fondasi untuk protein dan polipeptida (Aguzey et al., 2020). Ayam memiliki kebutuhan mutlak akan arginine dan sangat bergantung pada pola makan sumber asam amino ini. Agrinine harus cukup tersedia dalam pakan untuk mendukung pertambahan protein dan mencapai fungsi fisiologis dan imunologis (Khajali dan Wideman, 2010). Murakami et al. (2012) menyatakan bahwa $L$-arginine adalah stimulator penting pelepasan hormon pertumbuhan. L-arginine dapat meningkatkan massa otot (Fernandes et al., 2009). Selain itu, L-arginine juga merupakan asam amino basa yang memiliki peran utama sebagai stimulator amino lainnya asam sepert prolin, ornithine, glutamine, dan creatine (Al Daraji et al., 2012). Fouad et al. (2012) menyatakan senyawa yang berperan penting dalam aktivitas fisiologis ayam seperti oksida nitrat, poliamina, dan dimetil arginin. Berdasarkan uraian-uraian tersebut maka telah dilakukan penelitian dengan judul pengaruh suplementasi L-arginine dalam pakan terhadap pertambahan bobot badan, konsumsi pakan dan konversi pakan ayam broiler.

\section{METODE PENELITIAN}

\subsection{Tempat dan Waktu Penelitian}

Penelitian ini telah dilaksanakan dikandang Fakultas Petanian Universitas Timor, Kelurahan Sasi, Kecamatan Kota Kefamenanu, Kabupaten Timor Tengah Utara. Penelitian ini dilaksanakan pada bulan Maret-Mei 2021.

\subsection{Materi Penelitian}

Ternak yang digunakan dalam penelitan ini adalah ayam padaging (broiler) DOC (day old chick) dengan jumlah 96 ekor. Kandang yang digunakan dalam penelitian ini adalah kandang liter yang berukuran 7 x 3,5 $\mathrm{m}$ dan tinggi atap $3 \mathrm{~m}$, didalam kandang tersebut dibuat 16 unit kandang dengan ukuran $0,8 \times 0,7 \mathrm{~m}$, Dinding unit kandang terbuat dari kawat. Bahan yang digunakan dalam penelitian ini adalah pakan komersial BR1 BR2 yang disuplementasi dengan asam amino L-arginine serta air minum yang diberikan secara ad libitum. Peralatan yang digunakan dalam penelitian ini adalah 16 buah tempat pakan, 16 buah tempat minum, lampu pijar, timbangan merk idea life kapasitas $5 \mathrm{~kg}$ dengan tingkat ketelitian $1 \mathrm{~g}$ untuk menimbang ternak dan pakan. Peralatan lain yaitu kamera, pita ukur, jangka sorong, pisau, alat tulis, alat pembersih kandang seperti sapu, ember, dan skop.

\subsection{Metode Penelitian}

Penelitian ini menggunakan rancangan acak lengkap pola searah dengan 4 perlakuan dan 4 ulangan. Setiap ulangan terdiri dari 6 ekor ayam broiler. Perlakuan yang diberikan adalah:

T0: Pakan kontrol (BR 1 dan BR2)

T1: $99,5 \%$ pakan BR1/BR2 + 0,5\% L-arginine

$\mathrm{T} 2: 99,25 \%$ pakan $\mathrm{BR} 1 / \mathrm{BR} 2+0,75 \%$ L-arginine

T3: $99,00 \%$ pakan BR1/BR2 + 1,00\% L-arginine.

\subsection{Prosedur Penenlitian}

Tahap tahap yang dilakukan dalam penelitian ini adalah:

a) Persiapan kandang

Seluruh ruangan kandang dibersikan dan dicucihamakan dengan antiseptik, peralatan seperti tempat makan dan tempat minum dibersihkan, persiapan bahan kandang seperti alas kandang menggunakan sekam dan kapur, meletakkan koran diatas liter untuk anak ayam umur 1-7 hari, dan pemasangan bola lampu.

b) DOC tiba dan tindakan selanjutnya adalah:

DOC diistirahatkan, Pemberian air gula pada DOC, Pemberian pakan awal yang diberikan di tempat makan yang telah disiapkan, pemberian air minum dicampur dengan vitamin, dan penimbangan bobot awal (3 hari) untuk beberapa sampel ayam. 
a) Pada umur 4 hari dilakukan vaksinasi jenis ND1 melalui tetes mata.

b) Pemberian pakan dan air minum yang dicampur dengan vitamin hingga ayam berumur 10 hari.

a. Penempatan ayam didalam kandang dilakukan secara acak sesuai perlakuan.

c) Adaptasi pakan dilakukan selama 3 hari pada 18- 20 hari.

d) Pemberian perlakuan pertama pada hari ke-21 sampai panen.

e) Prosedur pemberian pakan. Pakan yang diberikan secara ad libitum

f) Penimbangan bobot badan dilakukan setiap minggu untuk mengetahui pertumbuhan dan perkembangan.

g) Pengambilan data selama penelitian berlangsung

Pengambilan data dilakukan dengan menimbang bobot badan awal dan dilakukan setiap minggu untuk mengetahui pertambahan bobot badan, dan menimbang sisa pakan yang diberikan untuk mengetahui konsumsi pakan.

Konversi pakan dapat dihitung dengan data pertambahan bobot badan dan konsumsi pakan dengan rumus.

\subsection{Variabel Penelitian}

Variabel yang diamati dalam penelitian ini adalah :

Pertambahan bobot badan diperoleh melalui pengukuran kenaikan bobot badan dengan melakukan penimbangan berat awal pada awal perlakuan umur 21 hari dan selanjutnya penimbangan dilakukan setiap minggu sampai panen.

$$
\mathrm{PBB}=\frac{\text { Berat akhir }- \text { berat awal }}{\text { Lama waktu penelitian }}
$$

Konsumsi pakan diperoleh dari jumlah pakan yang dikonsumsi per ekor ayam selama penelitian (g/ekor/hari).

$$
\text { Konsumsi Pakan }=\frac{\text { Jumlah pakan yang diberikan }- \text { Sisa pakan }}{\text { Konversi pakan merupakan ternak }}
$$
konsumsi pakan dan pertambahan bobot badan.

$$
\text { Konversi Pakan }=\frac{\text { Jumlah Konsumsi Pakan }}{\text { Pertambahan Bobot Badan }}
$$

\subsection{Analisis Data}

Data yang diperoleh dianalisis menggunakan analisis variansi (Anova) sesuai dengan Rancang Acak Lengkap (RAL) dan dilanjutkan dengan uji Duncan berdasarkan Steel dan Torrie (1995). Model matematik dari rancangan sebagai berikut:

$$
\mathbf{Y i j}=\mu+\tau \mathbf{i}+\mathbf{E i j}
$$

Keterangan :

Yij = Nilai pengamatan yang diperoleh perlakuan ke-i dengan ulangan ke-j

$\mu \quad=$ Rerata nilai pengamatan umum

$\tau \mathrm{i}=$ Rerata nilai pengamatan karena perlakuan ke-i

$\varepsilon \mathrm{ij}=$ Eror percobaan karena perlakuan ke-i dan ulangan ke-j

\section{HASIL DAN PEMBAHASAN}

\subsection{Pengaruh Perlakuan Terhadap Pertambahan Bobot Badan Ayam} Broiler

Pertambahan bobot badan merupakan selisih antara bobot badan awal dan bobot badan akhir dan dibagi dengan total hari lama waktu

\begin{tabular}{|c|c|c|c|c|}
\hline \multirow{2}{*}{ Ulangan- } & \multicolumn{4}{|c|}{ Perlakuan } \\
\hline & $\mathrm{T}_{0}$ & $\mathrm{~T}_{1}$ & $\mathrm{~T}_{2}$ & $\mathrm{~T}_{3}$ \\
\hline 1 & 62,15 & 64,79 & 65,48 & 69,42 \\
\hline 2 & 63,91 & 66,21 & 72,70 & 68,20 \\
\hline 3 & 64,52 & 65,68 & 70,27 & 67,00 \\
\hline 4 & 63,43 & 66,90 & 77,55 & 67,61 \\
\hline Jumlah & 254,01 & 263,58 & 286,00 & 272,23 \\
\hline Rataan & $63,50 \pm 1,01^{\mathrm{c}}$ & $65,89 \pm 0,89^{\mathrm{bc}}$ & $71,50 \pm 5,03^{\mathrm{a}}$ & $68,06 \pm 1,03^{\mathrm{ab}}$ \\
\hline
\end{tabular}
penelitian (g/ekor/hari). Pengaruh suplementasi L-arginine dengan level berbeda terhadap rata-rata pertambahan bobot badan harian ayam broiler terlihat pada Tabel 1.

Tebel 1. Rata-rata pertambahan bobot badan ayam broiler (g/ekor/hari)

Rata-rata pertambahan bobot badan harian ayam broiler dari yang tertinggi yaitu perlakuan $\mathrm{T}_{2}(71,50 \pm 5,03 \mathrm{~g} / \mathrm{ekor} / \mathrm{hari})$ selanjutnya diikuti perlakuan $\mathrm{T}_{3} \quad\left(68,06 \pm 1,03\right.$ g/ekor/hari), perlakuan $\mathrm{T}_{1} \quad(65,89 \pm 0,89$ g/ekor/hari) dan terendah perlakuan $\mathrm{T}_{0}(63,50 \pm 1,01 \mathrm{~g} / \mathrm{ekor} / \mathrm{hari})$. Analisis sidik ragam menunjukkan bahwa perlakuan berpengaruh nyata $(\mathrm{P}<0,05)$ terhadap pertambahan bobot badan ayam broiler. Hasil uji Duncan menunjukkan bahwa perlakuan $\mathrm{T}_{2}$ tidak berbeda nyata dengan $\mathrm{T} 3$ namun berbeda nyata dengan $\mathrm{T} 1$ dan $\mathrm{T} 0, \mathrm{~T} 1$ dan $\mathrm{T} 3$ tidak berbeda nyata namun berbeda nyata dengan $\mathrm{T} 2$ dan $\mathrm{T} 0$ sedangkan antara $\mathrm{T} 0$ dan $\mathrm{T} 1$ tidak berbeda nyata. Suplementasi L-arginine dapat meningkatkan pertambahan bobot badan dibandingkan dengan perlakuan $\mathrm{T}_{0}$ (kontrol). Apabila level $L$ arginine dinaikan $1 \%$ pertambahan bobot badan cenderung menurun di bandingkan dengan level L-arginine $0,75 \%$. Hal ini menunjukkan bahwa penambahan asam amino L-arginine maksimal dalam pakan BR2 sebesar $0,75 \%$. Asam amino L-arginine memiliki peran penting untuk meningkatkan pertambahan bobot badan. AL-Daraji et al. (2012) menyatakan bahwa suplementasi arginine $0,2 \%, 0,4$ dan $0,6 \%$ meningkatkan sifat-sifat produksi ayam broiler, dan efektif untuk meningkatkan performa ayam broiler yang produktif. Arginin merangsang sekresi hormon pertumbuhan menekan sekresi somatostatin endogen itu Artinya harus digerakkan secara cepat dan signifikan dekatkan GH, GH diperlukan untuk pertumbuhan Alba-Roth et al. (1988).

Asam amino arginine memiliki peran penting dalam beberapa proses fisiologis seperti pertumbuhan dan perkembangan dan berfungsi sebagai prekursor protein, creatine, polyamines, 1-proline, berbagai hormon dan oksida-nitrat (Khajali dan Wideman, 2010). Zainuddin et al. (2005) menyatakan bahwa penambahan salah satu asam amino dalam pakan, harus memperhatikan asam amino yang lain karena apabila ditambahkan dalam jumlah yang berlebihan akan menimbulkan gangguan pada pertumbuhan ayam broiler. Menurut fadilah, (2005) Faktor yang mempengaruhi besar kecilnya pertambahan bobot badan ayam pedaging adalah terpenuhinya kebutuhan zat makanan ayam pedaging, sehingga konsumsi pakan memiliki korelasi positif dengan pertambahan bobot badan. Dari penelitian ini memperlihatkan bahwa dengan penambahan asam amino L-arginine mampu menyediakan kebutuhan produksi ayam broiler yang tercermin lewat pertambahan bobot badan. Disamping itu pula Uzer et al. (2013) menyatakan bahwa faktor yang mempengaruhi pertambahan bobot badan yaitu perbedaan jenis kelamin, konsumsi pakan, lingkungan, bibit, dan kualitas pakan.

\subsection{Pengaruh Perlakuan Terhadap Konsumsi Pakan Ayam Broiler}

Konsumsi pakan merupakan selisih antara pakan yang diberikan dan sisa pakan dibagi dengan total hari lama waktu penelitian (g/ekor/hari) Pengaruh suplementasi L-arginine dengan level berbeda terhadap konsumsi pakan ayam broiler terlihat pada Tabel 2 .

Tabel 2. Rata-rata konsumsi pakan ayam broiler (g/ekor/hari)

\begin{tabular}{ccccc}
\hline \multirow{2}{*}{ Ulangan } & \multicolumn{4}{c}{ Perlakuan } \\
\cline { 2 - 5 } 1 & $\mathrm{~T}_{0}$ & $\mathrm{~T}_{1}$ & $\mathrm{~T}_{2}$ & $\mathrm{~T}_{3}$ \\
\cline { 2 - 5 } 1 & 123,68 & 124,52 & 124,07 & 125,53 \\
2 & 122,93 & 125,33 & 123,63 & 125,38 \\
3 & 122,51 & 124,60 & 124,36 & 125,16 \\
4 & 121,52 & 124,15 & 141,01 & 125,28 \\
Jumlah & 490,64 & 498,60 & 513,07 & 501,36 \\
Rataan & $122,66 \pm 0,90$ & $124,65 \pm 0,49$ & $128,27 \pm 8,50$ & $125,34 \pm 0,15$ \\
\hline
\end{tabular}

Keterangan: a,b,c superskrip pada baris rataan menunjukkan perbedan $(P<0,05)$

Rata-rata konsumsi pakan ayam broiler dari yang tertinggi pada perlakuan $\mathrm{T}_{2}$ sebanyak $\left(128,27 \pm 8,50\right.$ g/ekor/hari) diikuti perlakuan $\mathrm{T}_{3}$ $\left(125,34 \pm 0,15\right.$ g/ekor/hari), perlakuan $\mathrm{T}_{1}(124,65 \pm 0,49 \mathrm{~g} / \mathrm{ekor} / \mathrm{hari}) \mathrm{dan}$ perlakuan $\mathrm{T}_{0}(122,66 \pm 0,90 \mathrm{~g} / \mathrm{ekor} / \mathrm{hari})$. Hasil analisis sidik ragam menunjukkan bahwa perlakuan berpengaruh tidak nyata terhadap konsumsi pakan ayam broiler. Namun, nilai rata-rata pada perlakuan T1,T2 dan T3 lebih tinggi dibandingkan dengan T0 (kontrol). Hal ini menunjukkan bahwa kandungan L-arginine dalam pakan BR2 tidak mempengaruhi konsumsi pakan ayam broiler. Carew et al, (1997) menyatakan bahwa pakan yang kekurangan L-arginine akan mengurangi konsumsi pakan, pertambahan bobot badan dan pertumbuhan. Konsumsi pakan yang sama dari semua perlakuan menunjukkan tidak adanya perbedaan kebutuhan energi metabolisme maupun protein. Widjastuti dan Garnida (2005) menyatakan bahwa ayam mengkonsumsi pakan digunakan untuk memenuhi kebutuhan energinya dan bila telah terpenuhi maka ayam akan berhenti makan. Demikian pula menurut Gultom, (2014) bahwa konsumsi protein yang tepat akan mempengaruhi tercukupinya kebutuhan untuk metabolisme sel-sel dalam tubuh berlangsung secara normal.

Konsumsi pakan dipengaruhi oleh beberapa faktor, yaitu secara umum konsumsi meningkat dengan meningkatkan umur dan berat badan karena berat badan ayam yang besar mempunyai kemampuan menampung makanan lebih banyak (Wahju, 2004). Bell dan Waever (2002) menyatakan bahwa faktor-faktor yang dapat mempengaruhi tingkat konsumsi pakan antara lain yaitu berat badan, galur, tingkat produksi, tingkat cekaman, aktivitas ternak, kandungan energi dalam pakan dan suhu lingkungan. Dari penelitian ini menggambarkan bahwa penambahan asam amino L-arginine tidak mempengaruhi konsumsi pakan ayam broiler secara negatif. 
3.3 Pengaruh Perlakuan Terhadap Konversi Pakan Ayam Broiler

Konversi pakan merupakan perbandingan antara konsumsi pakan dan pertambahan bobot badan. Pengaruh suplementasi L-arginine terhadap rata-rata konversi pakan terlihat pada Tabel 3.

Tabel 3. Rata-rata konversi pakan ayam broiler

\begin{tabular}{ccccc}
\hline \hline \multirow{2}{*}{ Ulangan } & \multicolumn{4}{c}{ Perlakuan } \\
\cline { 2 - 5 } 1 & $\mathrm{~T}_{0}$ & $\mathrm{~T}_{1}$ & $\mathrm{~T}_{2}$ & $\mathrm{~T}_{3}$ \\
2 & 1,99 & 1,92 & 1,89 & 1,81 \\
3 & 1,92 & 1,89 & 1,70 & 1,84 \\
4 & 1,90 & 1,90 & 1,77 & 1,87 \\
Jumlah & 1,92 & 1,86 & 1,82 & 1,85 \\
Rataan & 7,73 & 7,57 & 7,18 & 7,37 \\
Keterangan: a,b,c superskrip pada baris rataan menunjukkan perbedan
\end{tabular}
$(P<0,05)$

Rata-rata konversi pakan ayam broiler dari yang tertinggi perlakuan T0 $(1,93 \pm 0,03)$ selanjutnya diikuti perlakuan $\mathrm{T} 1(1,89 \pm 0,02)$, perlakuan $\mathrm{T}_{3}$ $(1,84 \pm 0,06)$ dan terendah perlakuan $\mathrm{T}_{2}(1,80 \pm 0,08)$. Analisis sidik ragam menunjukkan bahwa perlakuan berpengaruh nyata $(\mathrm{P}<0,05)$ terhadap konversi pakan ayam broiler. Semakin meningkat level L-arginine dalam pakan angka konversi pakan semakin menurun atau semakin meningkat efisiensi penggunaan pakan ayam broiler untuk menghasilkan bobot badan. Hasil uji Duncan menunjukkan bahwa T0 dan T1 tidak berbeda nyata namun berbeda nyata dengan $\mathrm{T} 2$ dan $\mathrm{T} 3, \mathrm{~T} 2$ tidak berbeda nyata dengan $\mathrm{T} 3$ namun berbeda nyata dengan T1 dan T0. Suplementasi L-arginine dalam pakan pada perlakuan $\mathrm{T}_{2}$ sebanyak $0,75 \%$ menghasilkan konversi pakan terbaik. Apabila dinaikan menjadi 1\% maka angka konversi pakan meningkat. Tinggi rendahnya angka konversi pakan disebabkan oleh selisih yang semakin besar atau kecilnya pada perbandingan antara konsumsi pakan dan pertambahan bobot badan. Hal ini juga terlihat pada Tabel 3, dimana suplementasi $0,75 \%$ L-arginine menghasilkan pertambahan bobot badan yang terbaik.

Suplementasi L-arginine sebanyak $0,75 \%$ memberi respon maksimal tehadap pertumbuhan dan semakin efisien menggunakan pakan yang di konsumsi untuk meningkatkan bobot badan per satuan berat. Suplementasi L-arginine $0,75 \%$ meningkatkan konsumsi pakan, pertambahan bobot badan dan menghasilkan angka konversi pakan yang terbaik. Kwak et al. (1999) menyatakan bahwa ketersediaan arginine untuk sintesis protein, dirangsang oleh sekresi hormon glukagon, insulin dan hormon pertumbuhan (growth hormon) yang mungkin terjadi dan kemudian akan meningkatkan sintesis protein dan asupan pakan serta meningkatkan produksi ornithine yang berpengaruh terhadap sintesis DNA dan proliferasi sel.

Hormon pertumbuhan merupakan salah satu hormon terpenting yang mengatur glukosa dan asam amino di jaringan utama termasuk otot rangka, jaringan adiposa, hati dan jantung (Meijer dan Dubbelhis, 2004). Amrullah, (2004) menyatakan bahwa konversi pakan untuk ayam broiler berkisar antara 1,75-2,00. Dilanjutkan oleh Allama et al. (2012) bahwa nilai konversi pakan yang rendah menunjukkan efisiensi penggunaan pakan semakin baik serta semakin efisien ayam menggunakan pakan untuk memproduksi daging. Semakin tinggi angka konversi pakan menunjukkan semakin banyak pakan yang dibutuhkan untuk menaikkan bobot badan per satuan berat, dan sebaliknya jika semakin rendah angka konversi pakan berarti kualitas pakan semakin baik untuk menghasilkan pertambahan bobot badan (Lacy dan Vest, 2000). Selain itu Adil et al. (2010) menyatakan bahwa secara umum faktor yang mempengaruhi konversi pakan yaitu genetik, temperatur, ventilasi, sanitasi, kualitas pakan, jenis pakan, penggunaan zat additive, kualitas air, penyakit, dan tatalaksana pemeliharaan.

\section{KESIMPULAN}

Dari penelitian ini disimpulkan bahwa suplementasi L-arginine sebanyak $0,75 \%$ meningkatkan pertambahan bobot badan sebesar $71,50 \pm 5,03 \mathrm{~g} / \mathrm{ekor} / \mathrm{hari}$ dan konversi pakan sebesar $1,80 \pm 0,08$ pada ayam broiler.

\section{DAFTAR PUSTAKA}

Adil, S., T. Banday, G. A Bhat, M. S Mir and M. Rehman. 2010. Effect of dietary supplementation of organic acids on performance, intestinal histomorphology, and serum biochemistry of broiler chicken. Veterinary Medicine International. 7: 479-485.

Aguzey, H., G. Zhenhua, H. Wu, G. Cheng, Z. Wu, J. Chen and L. Niu. 2020. The role of arginine in disease prevention, gut microbiota modulation, growth performance and the immune system of broiler chicken. A Review. Annals of Animal Science. 20. 325341.

Alba-Roth, J.,O. A. Muller, J. schopohl and K. Von Werder, 1998. Arginine stimulates growth hormone secretion by suppressing endogenous somatostatin secretion. J. Ciln. Endocrinol. Metab. 67: 1186-1189.
Al-Daraji H. J., A. A. Al-Mashadani, W. K. Al-Hayani, A. S. Al-Hassani and H. A. Mirza. 2012. Effect of in ovo injection with L- $L$ arginine on productive and physiological traits of Japanese quail. South African Journal of Animal. Science. 42(2): 139-145.

Al-Daraji H. J., and S. A. M. Salih. 2012. Effect of dietary L-arginine on producyive performance of broiler chicken. Pakistan Journal of Nutrition.11(3): 252-357.

Allama, H., O. Sofyan, E. Widodo dan H. S. Prayogi. 2012. Pengaruh penggunaan tepung ulat kandang (Alphitobius diaperinus) dalam pakan terhadap penampilan produksi ayam padaging. Jurnal ilmuilmu peternakan. 22(3): 1-8.

Amrullah, I. K. 2004. Nutrisi Ayam Petelur. Cetakan ke-3. Lembaga Satu Gunung Budi. Bogor.

Badan Pusat datistik dari https://www.bps.go.id/indicator/24/478/1/ populasi-ayam-raspedaging-menurut-provinsi.Html. [Diakses Pada tanggal 23 Oktober 2020].

Bell, D. D. and W. D. Weafer. 2002. Commercial Chicken Meat and Egg Production. 5 th edition. Springer Science Bussines. Inc. Spiring Street. New York.

Carew,1. B., K. G. Evert and F. A. Alster, 1997. Growth and plasma thyroid hormone concentrations of chicks fed diets deficient in essential amino acids. Poult. sci. 76: 1398-1404.

Fadilah. 2005. Panduan Mengelola Peternakan Ayam Broiler Komersial. Agromedia. Pustaka. Jakarta.

Fernandes, J. I. M., A. E. Murakami, E. N. Martins, M. I. Sakamoto, and E. R. M Garcia. 2009. Effect of arginine on the development of the pectoralis muscle and the diameter and the protein: deoxyribonucleic acid rate of its skeletal myofibers in broilers. Poultry Science. 88: 1399-1406.

Fouad A. M., H. K El-Senousey, X. J. Yang and J. H. Yao. 2012. Role of dietary L-arginine in poultry production. Internatoinal Jurnal Poultry Science. 11: 718-729.

Gultom, S. M., R. D. H. Supratman, dan Abun. 2014. Pengaruh imbangan energi dan protein ransum terhadap bobot karkas dan bobot lemak abdominal ayam broiler umur 3-5 minggu. Students e-Journal. 1(1): $1-5$.

Herlina. B, N. Ririn dan K. Teguh. 2015. Pengaruh Jenis dan Waktu Pemberian Ransum terhadap Performans Pertumbuhan dan Produksi Ayam Broiler. Jurnal Sain Peternakan Indonesia. Vol, 10. No 2:107-113.

Khajali, F. and R. F. Wideman, 2010. Dietary arginine: Metabolic, environmental, immunological andphysiological interrelationships. World's Poult. Sci. J. 66: 751-766.

Lacy M and R Vest. 2000. Improving feed conversion in broiler: a guide for growers. Springer science and business media inc. New York.

Meijer, A.J. and P.F. Dubbelhis, 2004. Amino acid signaling and the integration of metabolism. Biochem. Physiol. 313: 397-403

Murakami, A. E., J. I. M. Fernandes, L. Hernandes and T. C. Santos. 2012. Efect of starter diet supplementation with arginineon broiler production performance and on small intestine morphometry. Brazilian journal of veterinary research. 32(3): 259-266.

Nuriyasa, I. M. 2003. Pengaruh tingkat kepadatan dan kecepatan angin dalam kandang terhadap indeks ketidaknyamanan dan penampilan ayam pedaging. Majalah Ilmiah Peternakan, Fakultas Peternakan, Universitas Udayana. Danpasar. Halaman 99-103.

Suprijatna, E. 2010. Strategi pemanfaatan pakan sumber daya lokal dan berwawasan lingkungan. Prosiding seminar nasional unggas lokal ke IV. Halaman. 55-79.

Uzer, F., N. Iriyanti dan Roesdiyanto. 2013. Penggunaan pakan fungsional dalam ransum terhadap konsumsi pakan dan pertambahan bobot badan ayam broiler. J. Ilmiah Peternakan. 1(1): 282-288.

Wahju, J. 2004. Ilmu Nutrisi Unggas. Gadjah Mada University Press. Yogyakarta.

Widjastuti, T., dan D. Garnida. 2005. Evaluasi Performans Ayam Merawang Fase Pertumbuhan (12 Minggu) Pada Kandang Sistem Kawat Dan Sistem Litter Dengan Berbagai Imbangan Energi Dan Protein Di Dalam Ransum. Prosiding Lokakarya Nasional Inovasi Teknologi Pengembangan Ayam Lokal. Balai Penelitian Ternak. Bogor.

Yuwanta, T. 2004. Dasar Ternak Unggas. Penerbit Kanisius. Yogyakarta.

Zainuddin, D. 2005. Strategi pemanfaatan pakan sumber daya lokal dan perbaikan manajamen ayam lokal. Lokakarya nasional teknologi pengembangan ayam lokal. Balai penelitian ternak. Bogor. 